\title{
30. PALEOGLACIAL HISTORY OF ANTARCTICA INFERRED FROM ANALYSIS OF LEG 29 SEDIMENTS BY SCANNING-ELECTRON MICROSCOPY
}

\author{
Stanley V. Margolis, Department of Oceanography and Hawii Institute of \\ Geophysics, University of Hawaii, Honolulu
}

\section{INTRODUCTION}

One of the major goals of Leg 29 was to extend our knowledge of the history of Antarctic glaciations initially outlined by Margolis and Kennett (1971) by a study of the occurrence of ice-rafted sediments contained in subantarctic deep-sea cores. In previous studies of this nature, scanning-electron microscopy (SEM) was used to identify quartz grains of glacial origin contained in Eltanin cores of Eocene and Oligocene age from the southeastern Pacific sector of the Southern Ocean (Margolis and Kennett, 1971). The oldest evidence of ice-rafted sediments from the southeastern sector of the Indian Ocean (the area covered by Leg 29) had been described by Kennett and Brunner (1973) and Blank and Margolis (in press) as being of late Miocene-early Pliocene age. Hayes et al. (1973) had noted the presence of ice-rafted debris of early and middle Cenozoic age, recovered during DSDP Leg 28; however, there is a strong possibility that this material may have been sucked into the drill string from the sea floor and fallen down the pipe, to be included as contaminant in older sediments. Any conclusions concerning Leg 28 paleoglacial history will await the publication of their initial reports.

It was anticipated that the sediments recovered during Leg 29 would contain a fairly complete record of the variations in amounts of ice-rafted sediments delivered to this sector of the Southern Ocean from Antarctica during the Cenozoic and late Mesozoic.

\section{METHODS}

Ten-cc samples were obtained from relatively undeformed portions of the drill cores. Smear slides prepared onboard ship were used as indicators of intervals containing appreciable sand. Samples were also obtained from all core catchers. The samples were weighed dry, washed over a $44 \mu$ sieve, and the dry residue weighed after being allowed to reach room temperature. The samples also were treated with $15 \%$ $\mathrm{HCl}$ to digest the calcium carbonate to concentrate siliceous detrital components. Techniques used are similar to those routinely performed in DSDP laboratories. After drying, the coarse fractions were examined with a binocular microscope, and the following descriptions were made: (1) principal biogenic components, (2) abundance and types of detrital minerals, (3) abundance and types of volcanic sediments, (4) abundance and types of authigenic components. The abundance of quartz grains in each sample was determined by direct point-counting. Those samples containing large numbers of grains were separated into splits using an Otto microsplitter, to a level where the quartz grains were countable in a reasonable length of time. Estimates of the total number of grains in a sample were made by multiplying by the number of splits taken. After counting, 25 unicrystalline quartz grains were randomly selected from each sample and mounted on 2.54$\mathrm{cm}$-diameter aluminum plugs using either duco cement (smaller grains) or silver paste (large grains). They were then coated with a thin carbon film in a vacuum evaporator. The grains were then examined with a Cambridge S4-10B SEM for diagnostic surface features as described by Margolis and Kennett (1971).

Indications were made as to whether the grains exhibited glacial, subaqueous abrasion, eolian, and chemical etch or precipitation features. In addition, each grain was analyzed with an EDAX energy-dispersive $\mathrm{X}$ ray fluorescence system, attached to the SEM. This was done to check the chemical composition of the grains to insure that they were indeed quartz, as small grains of clear volcanic glass and sanidine can easily be mistaken for quartz during rapid counting with a binocular microscope.

\section{RESULTS}

\section{Site 275, Southeastern Edge of Campbell Plateau}

Twelve samples were examined from the 62 meters of Upper Cretaceous sediment drilled at this site. Abundant fine quartz grains are found throughout all the samples. Quartz grains of glacial origin (Plate 1, Figures $1,2)$, however, are found only in Upper Cretaceous sediments contaminated with Pleistocene foraminifera, indicating that the larger glacial quartz grains were probably also out of sequence. As described elsewhere in this volume (Chapter 2) surface manganese nodules similarly contaminate cores at this site.

Quartz grains from undisturbed and uncontaminated Upper Cretaceous portions exhibit evidence of subaqueous transport by bottom currents and are well sorted.

The presence of glacial quartz grains in the surficial veneer of Recent to Pleistocene age is an indication that icebergs from Antarctica traveled at least this far north in Recent times. Alternatively perhaps, these grains had their source from glacial deposits adjacent to New Zealand that were reworked and deposited here as a lag sediment along with the manganese nodules. Lack of any quartz grains of glacial origin in sediments of Upper Cretaceous age does not conclusively rule out the possibility of Antarctic glaciation at that time. The great unconformity between the Recent and Upper Cretaceous sediments indicates erosion or nondeposition perhaps caused by an active western boundary current. 


\section{Site 276, Beyond Southeastern Edge of Campbell Plateau}

Quartz sand grains recovered from the bit and corecatcher samples taken at this site exhibited the following types of surface features: (1) coatings with iron and manganese, (2) smooth, polished surfaces consisting of a thin layer of precipitated silica (see also Ovenshine et al., this volume), (3) fractures and breakage patterns possibly produced during the drilling. Since the age range of these two samples was very broad, no meaningful paleoglacial history could be deduced from this site.

\section{Site 277, Southern Campbell Plateau}

Quartz grains and other detrital minerals were concentrated in only rare portions of this predominantly pelagic carbonate sequence. Concentrations were found in Cores 1, 2, 25, 26, and 27. Examination of these grains with the SEM revealed that they were transported by subaqueous bottom currents; no paleoglacial history was evident in these sediments.

\section{Site 278, Emerald Basin}

This site, close to the present-day Antarctic convergence, was anticipated to be the most informative section in terms of paleoglacial history. The PlioPleistocene portion of this site exhibited a variable fluctuation in the abundance of quartz grains of glacial origin (Plate 1, Figures 3-6) similar to that found in Eltanin piston-cores from this same region by Kennett and Brunner (1973) and Blank and Margolis (in press). Quartz abundances in the Pliocene portions were comparable to those in the Pleistocene portion (Figure 1). In fact, the greatest concentration of glacial quartz and granitic rock fragments was found at the bottom of Core 8 (late Pliocene) immediately above an unconformity on early Pliocene sediments. Below Core 8, however, glacial quartz decreases significantly (from tens of thousands to below 200), as the sediment type changes from a diatom ooze to a nannofossil ooze and the sedimentation rate decreases. In Cores 9-15, the number of quartz grains fluctuates between $0-180$ per sample, and those present are usually around $1-2 \mathrm{~mm}$ in diameter. No evidence of quartz of glacial origin was found below Core 15 .

In Core 16 and below (mid Miocene), small grains which were similar in appearance to quartz were mistakenly identified as such onboard ship. After analysis using X-ray diffraction and fluorescence in our laboratories, it was found that these clear, angular grains found below Core 15 , and which exhibit conchoidal fracture and lack cleavage, were actually sanidine and plagioclase glass fragments (Plate 2, Figures 5,6). Peaks in the abundance of these feldspars are found in the coarse fractions of Cores 18,20, and 34 . In all cases the coarse fractions are associated with very abundant basaltic volcanic ash and rock fragments, which could have been derived from volcanism from the nearby MacQuarie Ridge.

The paleoglacial history found in the coarse fractions at Site $\mathbf{2 7 8}$ based on the presence of glacial quartz is therefore restricted to late to middle Miocene (?) and younger sediments. Examination of Figure 1 reveals no obvious trend in glacial quartz abundance, although the curve appears cyclic, and certain intervals seem to be

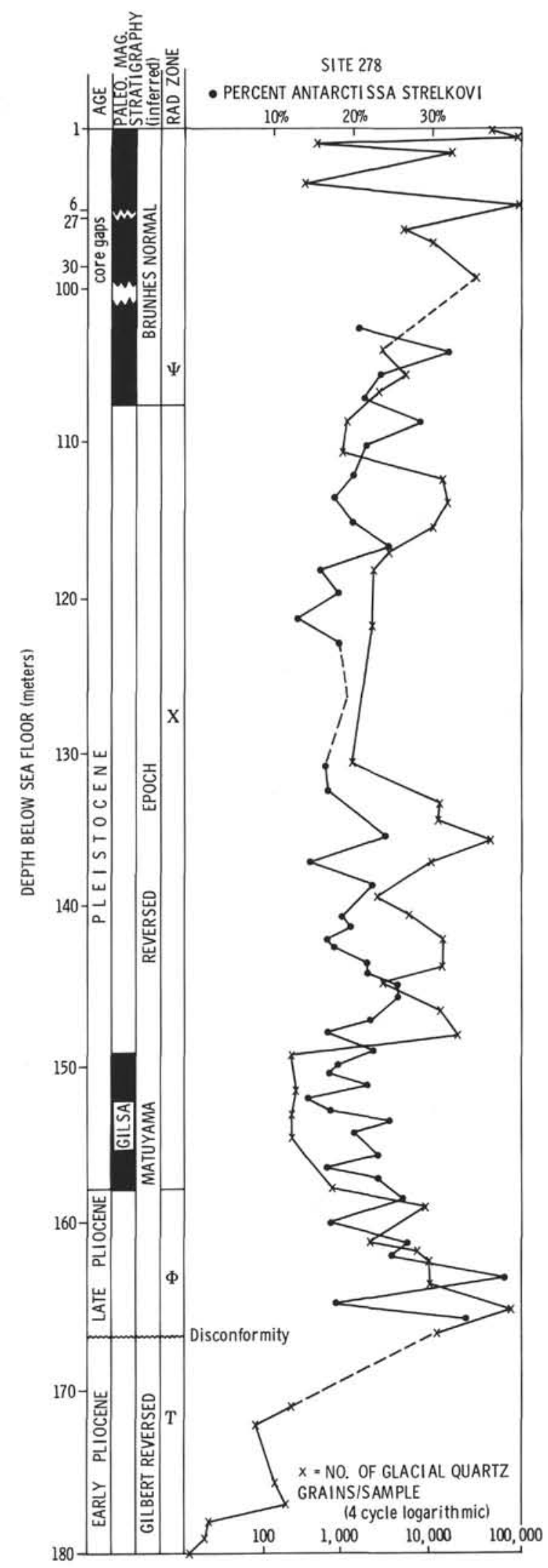

Figure 1. Variations in the numbers of quartz grains $>44 \mu$ of glacial origin, with depth in sediments at Site 278 (black line and + ). Scale used in 4-cycle logarithmic, due to the great fluctuations. Percent Antarctissa strelkovi data (red line and circles), and biostratigraphy is taken from Keany and Kennett (this volume). 
characterized by lower abundances and others by much higher amounts. Unfortunately the unconformity between the Pliocene and late Miocene spans a very critical period of time in the development of both Antarctic glaciation and Southern Ocean circulation patterns; but the gap itself may be indicative of erosion produced by an increase in bottom water activity associated with an increase in the tempo of Antarctic glaciation.

Variations in sand grain abundance are plotted in Figure 1 along with the frequency oscillations of the radiolarian Antarctissa strelkovi (Keany and Kennett, this volume) which has been shown by Keany (1973) to be more abundant during times of lower temperature. Figure 1 indicates that there is no direct correlation between lower temperatures and increases in the amounts of glacial quartz grains. If anything, certain portions of the curves exhibit an inverse relationship between these parameters - an increase in quartz grains associated with higher temperatures. A possible explanation for this could be that during colder times, icebergs floated north of Site 278 before encountering warmer waters, melting, and releasing their sediment load. During relatively warm times, which corresponded with peaks in glacial sediments, the ice-rafted limit may have been located closer to this site. The greater amount of melting here would result in relatively more ice-rafted sediments than during colder periods. Factors which could cause variations from this proposed scheme are changes in prevailing iceberg tracks, changes in availability of easily erodible sediments on Antarctica, and modifications of sediment after deposition by bottom currents. Additional studies using other paleoclimate-sensitive microfossils will be necessary to test the validity of this hypothesis.

In order to interpret the significance of the fluctuations shown in Figure 1 it will be necessary to correlate it with detailed paleooceanographic variations as indicated by additional micropaleontological studies and by oxygen isotope studies of the planktonic foraminifera, both of which are currently in progress. In this manner, fluctuations in degree of ice-rafting can be related to changes in oceanic surface water temperatures during the late Cenozoic. Closer sampling intervals will be necessary to define the periodicity, if any, of paleooceanographic and paleoglacial changes.

The absence of ice-rafted quartz grains and granitic rock fragments, $>44 \mu$ in diameter, in the lower Miocene and Oligocene sediments at this site does not mean that Antarctica was not glaciated at this time. Possible explanation for lack of such materials in sediments of this age, assuming the interpretations of Margolis and Kennett (1971) are correct concerning early Cenozoic Antarctic glaciations, could be: (1) Site 278 was north of the iceberg limit during the Oligocene and early Miocene; and (2) Since the evidence for Oligocene and Eocene glaciation of Antarctica was found in deep-sea cores collected from the Southern Ocean adjacent to western Antarctica, perhaps that region was glaciated before eastern Antarctica (Mercer, 1972).

\section{Mineralogy}

The following is a discussion of the distribution of quartz of glacial origin in the $>44 \mu$ fraction of samples from Site 278, of the inferred paleoglacial history, and of the X-ray diffraction data for this site. According to the bulk sample mineralogy, the percentage of quartz is reciprocal with the percentage of calcite. The greatest amount of quartz (Cores 16, 28) coincides with a lack of calcite, and the lowest amounts of quartz (Cores 3 and 13 ) is found in the cores with the most calcite. This could be interpreted as indicating that conditions that favor the sedimentation of foraminifera and nannofossil oozes are not optimum times for transport of quartz into the deep sea, either by ice-rafting, by wind, or by bottom currents; on the other hand, siliceous ooze deposition is associated with times of high productivity adjacent to the Antarctic convergence. These are also times during which more quartz is introduced into the deep sea in high latitudes by ice-rafting and other processes that are more active during peaks in glaciation.

The percentage of quartz in the bulk sample X-ray data does not correlate with the data from the grain counts in the $>44 \mu$ fraction performed in this study. This means that the quartz must be concentrated in the finer fractions. Higher percentages of quartz in the bulk sample are also associated with greater amounts of potassium and plagioclase feldspars, mica, and clay minerals. Apparently all of these detrital sediment components are being brought into the siliceous oozes along with the quartz, which may account for the higher sedimentation rates in comparison with calcareous oozes.

If we assume the observation is correct that ice-rafting is abundant only in Cores $1-8$, then according to the bulk sample mineralogy, the only mineral whose occurrence is restricted to this interval is amphibole. Crystals of hornblende were found in small metamorphic-rock fragments from the coarse fractions of Cores 1-8. Perhaps in this region, the presence of appreciable hornblende in deep-sea sediments from high latitudes can be used as an indicator of ice-rafting.

The mineral distribution in the $2-20 \mu$ and the $<2 \mu$ carbonate-free X-ray fractions gives no hint of variations in continental source or transport media other than the fact that amphibole again decreases appreciably below Core 8 in the $2-20 \mu$ fraction, and disappears in the $<2 \mu$ fraction below Core 13 .

One fact that stands out is that the presence of abundant fine feldspar and amphibole is an indication of very little chemical weathering, both in the source area on land and in the marine environment. Lack of chemical weathering is characteristic of desert and glacial environments, so the possibilities for the source of this fine material of silicic composition may be eolian dust blown in from desert regions of perhaps Australia, or of glacial rock flour, either transported by icebergs or carried in by bottom currents. There is also evidence for a significant but variable volcanic ash component in the sanidine and glass fragments found in the $>44 \mu$ fraction. 
Since all three of these sources are probably represented in Site 278 sediments, it would be difficult to differentiate between their relative contributions. However, the evidence of glacially derived quartz in Cores $1-15$ and the similarities in the mineralogies of these cores with Cores 16-34 favor the presence of glacially derived component in these samples as well, although the coarse material is absent. Additional evidence would be required, however, to conf irm this.

\section{Site 279, MacQuarie Ridge}

One ice-rafted rock fragment consisting of quartz and hornblende was found in the one core recovered at Site 279. This sample, of Pleistocene age, also contained abundant quartz sand grains of glacial origin. At Hole $279 \mathrm{~A}$, the Pleistocene portion of Core 1 contained about 150 glacial quartz grains (Sections 1 and 2). At the bottom of Core 1, Section 3 , there is a disconformity, below which the sediments are of middle Miocene age. The number of glacial quartz grains here decreases to 05 per sample (Cores 2 and 3 ), and then disappear altogether.

Transparent, angular grains with conchoidal fracture which occur below Core 3 were most abundant in Core 11 , Section 3. They consist of plagioclase feldspar, glass, and sanidine, associated with volcanic detritus. These grains had been identified as quartz onboard ship. X-ray diffraction studies again indicate that amphibole is present only in the sample which contains abundant glacially derived quartz.

\section{Site 280, South Tasman Rise}

No paleoglacial history was found at this site. All quartz grains examined exhibited subaqueously abraded surfaces, consistent with being terrigenously derived and deposited on the continental slope, adjacent to a land mass.

\section{Site 281, South Tasman Rise}

The only core of paleoglacial interest at this site was Core 17, which contained a mica schist breccia, and a quartz mica schist. The quartz grains in this portion showed a wide assortment of different shapes, morphologies, and surface textures-from rounded and polished grains to fresh unweathered and unabraded igneous quartz and microcrystals (Plate 2, Figures 5, 6) and a small number of definite glacial grains. It is difficult to determine the environment that could produce such a mixture of rock types, and quartz types. The core recovery was poor in this interval, so the possibility of their being thin beds of sedimentary rocks, mixed together by drilling, cannot be ruled out. Another possibility is that the breccia may be a basal glacialmarine till developed adjacent to a metamorphic (schist and quartzite) terrain. Evidence in support of this interpretation includes: (1) presence of some quartz grains with glacial surface features; (2) extremely poor sorting and variety of rock and mineral types found; (3) extreme angularity and fresh, unweathered appearance of rock fragments which indicates that they could not have traveled far from source area or subjected to much chemical alteration; (4) the fact that this region was located near Antarctica during the Eocene, and that there is evidence of Eocene Antarctic glaciation elsewhere (Margolis and Kennett, 1971).

Unfortunately this problem may never be resolved without additional drilling on the South Tasman Rise.

\section{Site 282, Southwestern Tasmania Continental Slope}

Epicontinental slope terrigenous detritus is abundant here, no sediments of glacial origin.

\section{Site $\mathbf{2 8 3}$}

No paleoglacial history.

\section{Site $\mathbf{2 8 4}$}

No paleoglacial history.

\section{SUMMARY}

Site 278 in the Emerald Basin contained the best evidence of Antarctic paleoglacial history as determined by ice-rafted sediments. The oldest glacially derived quartz found at this site was late middle Miocene in age. Plio-Pleistocene sediments at Site 278 contained largescale fluctuations in the amount of glacially derived quartz, from hundreds of grains to over 100,000 in each sample. These variations reflect changing climatic and sediment regimes as well as changes in the rate of supply of glacial-marine sediments by icebergs. When correlated with paleooceanographic data obtained from micropaleontological and oxygen isotope studies, these variations in glacially derived quartz will yield important evidence of late Cenozoic glacial history and what effect it had on oceanographic temperature and circulation patterns in the Southern Ocean. Glacially derived quartz grain concentrations drop down to extremely low levels $(<200$ per sample) below an unconformity between sediments of late Pliocene and early Pliocene age and disappear completely below Core 15 (late middle Miocene). No glacial grains were found in lower Miocene or Oligocene sediments in any Leg 29 cores.

Site 279 contains some glacial quartz in Pleistocene sediments, and a very small number of such grains ( 75 per sample) in middle Miocene sediments.

The mica-schist breccia immediately above basement at Site 281 contains some quartz grains with glacial surface features. However, the poor recovery and mixed nature of this deposit makes interpretation of its depositional environment highly speculative.

Ice-rafted sediments were also found in Pleistocene intervals at Sites 275 and 276 . Quartz grains were locally abundant in the $>44 \mu$ fraction of pre-middle Miocene intervals at nearly all sites, but SEM examination revealed that they were transported by bottom currents; therefore, the presence of quartz sand in a subantarctic deep-sea core does not necessarily imply a glacial origin.

There appears to be a correlation, however, in the presence of amphibole (hornblende) as detected by Xray diffraction studies and glacial quartz sand in the cores. This may imply a granodioritic or metamorphic source rock area on Antarctica, or perhaps New Zealand.

In future studies of this kind, it is essential that grains which resemble quartz be checked by petrographic and $\mathrm{X}$-ray identification. Sanidine and feldspathic glass, when examined only by binocular reflecting microscope, 
may be easily mistaken for fractured quartz, even by experts.

Absence of any ice-rafted sediments of Oligocene or Eocene age in sediments recovered during Leg 29 does not necessarily disprove the conclusions of Margolis and Kennett (1971). The cores they examined were from the southeastern Southern Ocean. Glaciation may have been initiated in western Antarctica in the early Cenozoic before extending to eastern Antarctica during the mid-to-late Cenozoic; alternatively the Leg 29 drill sites may have all been north of the iceberg limit prior to or during the Oligocene. Results of future Antarctic deep-sea drilling, and examination of Eltanin piston cores will perhaps extend our knowledge of early Cenozoic Antarctic glaciations.

\section{REFERENCES}

Blank, R. G. and Margolis, S. V., in press. Paleoceanography of the Southeastern Indian Ocean and paleoglacial history of Antarctica as revealed by Cenozoic Deep-Sea Sediments: Geol. Soc. Am. Bull.

Hayes, D. E. Frakes, L. A., Barrett, P., Burns, D. A., Chen, P.-H., Ford, A. B., Kaneps, A. G., Kemp, E. M., McCollum, D. W., Piper, D., Wall, R. E., and Webb, P. N., 1973, Deep-Sea Drilling in the Southern Ocean: Geotimes, v. 18, p. $19-24$.

Keany, J., 1973. New radiolarian paleoclimatic index in the Plio-Pleistocene of the Southern Ocean: Nature, v. 246, p. 139-141.

Kennett, J. P. and Brunner, C. A., 1973. Antarctic late Cenozoic glaciation: Evidence for initiation of ice-rafting and inferred increased bottom water activity: Geol. Soc. Am. Bull., v. 84, p. 2043-2055.

Margolis, S. V. and Kennett, J. P., 1971. Cenozoic paleoglacial history of Antarctica recorded in Subantarctic deep-sea cores: Am. J. Sci., v. 271, p. 1-36.

Mercer, J. H., 1972. Cainozoic temperature trends in the Southern Hemisphere: Antarctic and Andean glacial evidence: In Palaeoecology of Africa, van Zinderen Bakker, E. M., (Ed.) Capetown, (A. A. Balkema Publ.), p. 85-114. 


\section{PLATE 1}

Figures 1, 2 Quartz sand grains exhibiting glacial features, found in sediments from Site 275 of Pleistocene age.

Figure 3 Quartz grain of glacial origin, typical of those from sediments of Pleistocene through late Miocene age from Site 278.

Figures 4-6 High magnification photos of different regions of grain shown in Figure 3. Note sharp angular outline, conchoidal fractures, semiparallel steps, striations, and etched pitted surface.

PLATE 2

Figure 1 Grain of sanidine from Site 278, which was typical of those mistaken for quartz. This grain shows rectangular outline which gives a clue to its feldspathic composition, but the majority of such grains did not show cleavage.

Figures 2-4 High-magnification photos of sanidine grains from Site 278, showing surficial similarities with glacial quartz.

Figures 5, 6 Glacial features on quartz grains from Site 278; note similarity to sanidine grains.

(See p. 1046) 


\section{PLATE 1}
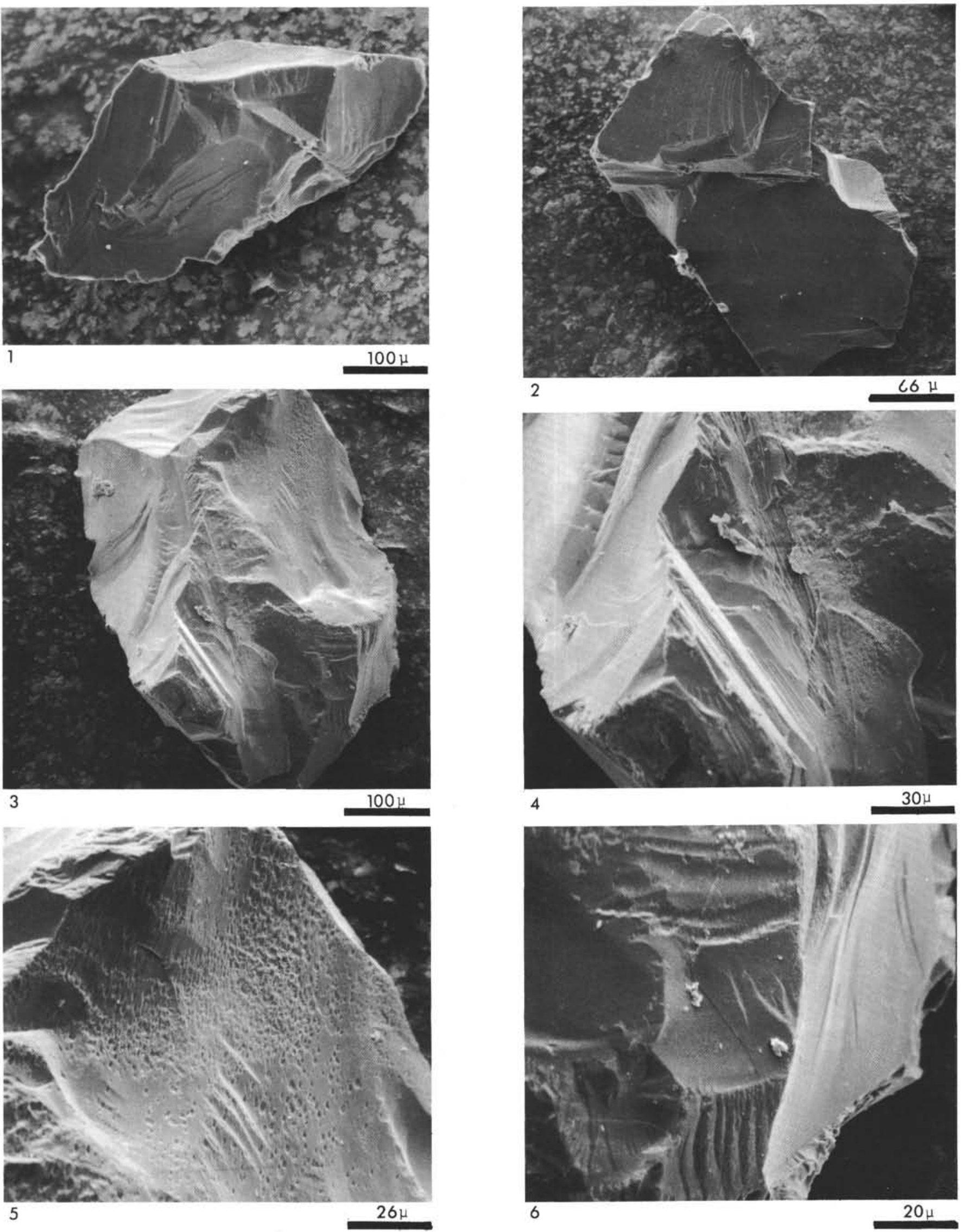


\section{PLATE 2}
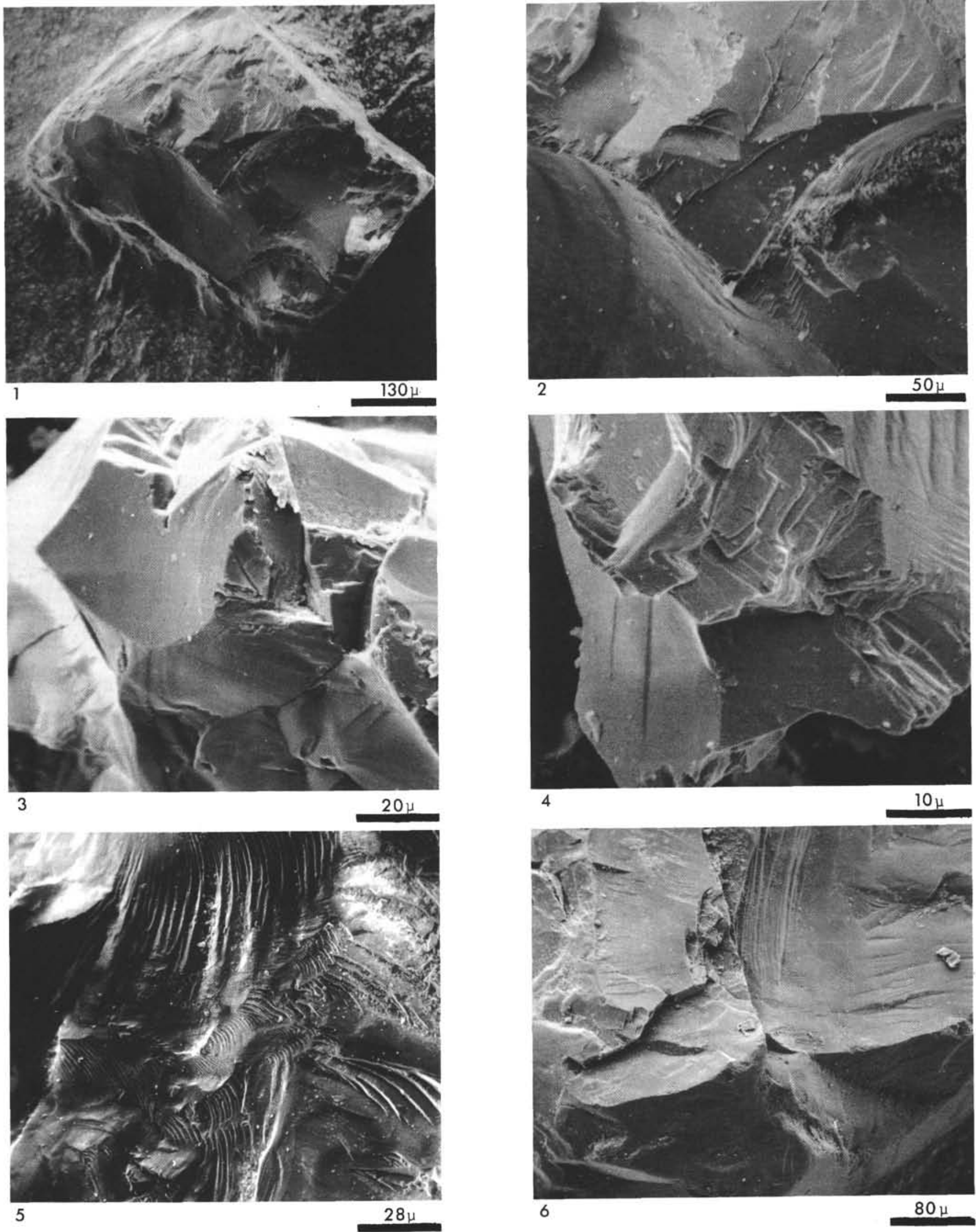

6 


\section{PLATE 3}

Quartz sand grains from the bottom of Core 17, Site 281. Note fresh angular outline, semiparallel steps, striations, and unweathered surfaces. These features are typical of grains of glacial origin, however, the mixed nature of the sediment from which they were sampled makes it difficult to interpret the significance or age of these grains.

(See p. 1048) 
PLATE 3
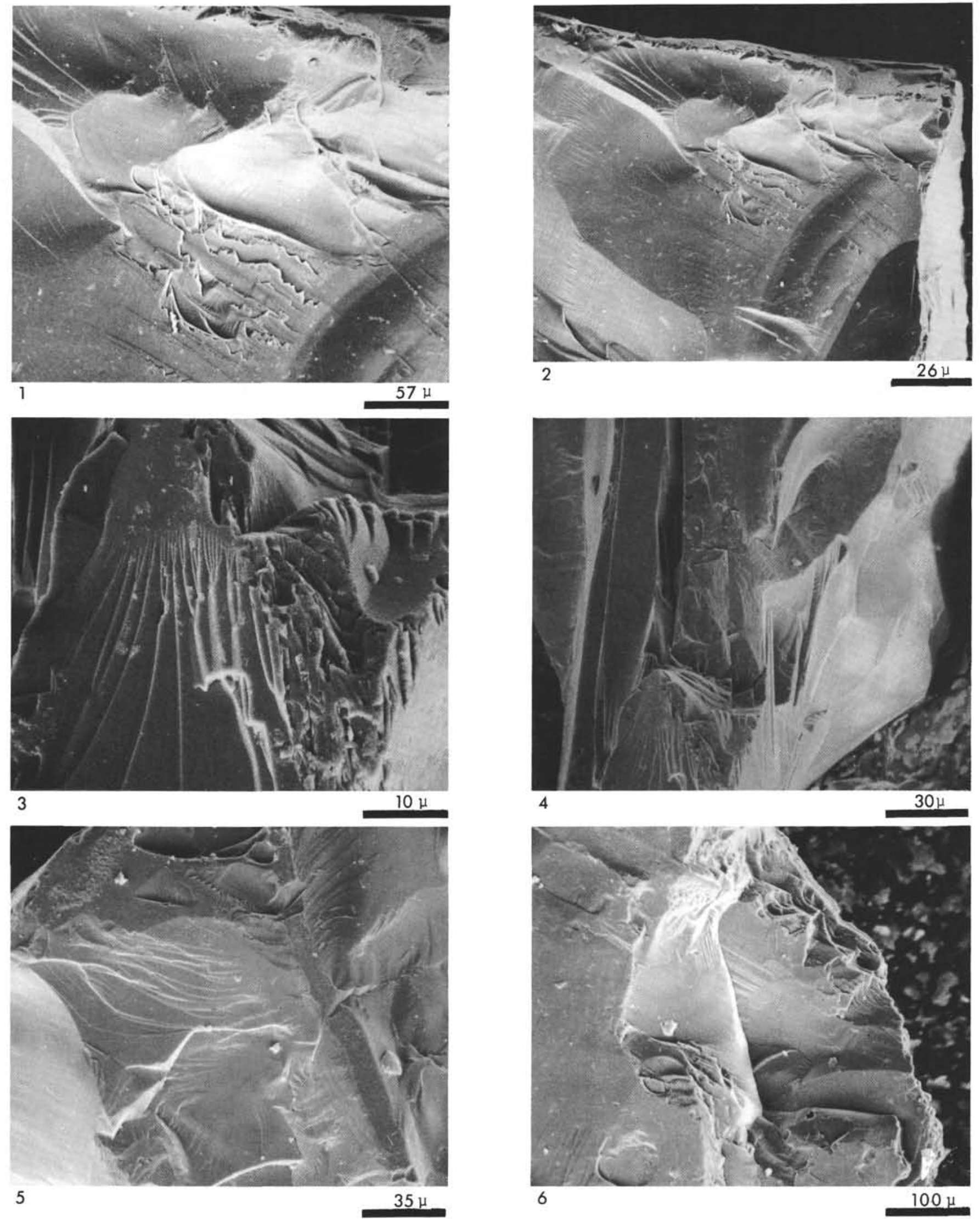